\title{
Psychological Images Of Parents Against Mental Retardation Children In SLB Negeri 1 Bulukumba
}

\author{
Haerani $^{1}$, Nurlina ${ }^{2 *}$,Sri Wahyuningasih ${ }^{3}$ \\ Departemen Of Child and Maternity Nursing, Stikes Panrita Husada Bulukumba, Indonesia ${ }^{1}$ \\ Departemen Mental Health Nursing, Stikes Panrita Husada Bulukumba ,Indonesia ${ }^{2}$ \\ S1 Nursing Study Program, Stikes Panrita Husada Bulukumba, Indonesia ${ }^{3}$
}

Corresponding Autor : Nurlinapanrita@gmail.com*

\begin{abstract}
Parents who have mentally retarded children will surely experience different challenges compared to those who have normal children. Parents whose children experience mental retardation usually get psychological pressure, resulting in stress and depression because parents feel lost hope for their children. The parents' emotional reactions immediately explode. The explosion of anger mixed with feelings of sadness, disappointment, frustration, pessimism, impatience, and shame. The purpose of this study was to determine the psychological description of parents of children with mental retardation in SLB Negeri 1 Bulukumba in 2018.The research method uses a descriptive design with a simple approach. The population in this study was 42 people. The research sample of 30 respondents. Data obtained through questionnaire sheets made by researchers to respondents. The results of this study showed that parents who experienced mild stress were 1 respondent $(3.3 \%)$, moderate stress were 23 respondents $(76.7 \%)$, while the level of severe stress was 6 respondents $(20.0 \%)$. Then those with high coping are 27 respondents, and low coping is 3 respondents $(10 \%)$. The conclusion from this study found that more parents experience moderate stress than mild and severe stress. Then, more parents have high coping than low coping.
\end{abstract}

\section{Keywords: Psychological Parent, Mental Retardation Child}

\section{INTRODUCTION}

Mental retardation or mental retardation is a disorder in which general intellectual functioning is below average. Those who are mentally retarded cannot take care of themselves according to their age (Apriyanto, 2012). According to WHO (World Health Organization) in 2017 reported mental disorders (disability) showed between 35\% and $50 \%$ in developed countries. Whereas in developing countries $76 \%$ and $85 \%$. While the number of children with special needs, mentally retarded children ranks second after children with disabilities with the number of children who experience mental retardation (30,460 children) of Indonesia's population (82,840,600 children). National Census Statistics Agency (BPS) year (2015) Indonesian population experiencing mental disability (8.56\%). Riskesdas Data (2013) South Sulawesi is the highest population 


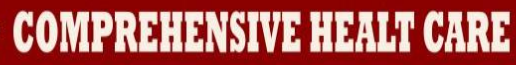

experiencing mental retardation (23.8\%), Central Sulawesi (19.6\%), West Sulawesi (13.4\%), and the lowest in West Papua (4.6\% ), Banten (5.1\%) DKI Jakarta (7.7\%), and Riau (8.5\%) including children over 15 years of age.

In children who experience mental retardation will experience several obstacles including learning in the process of intelligence caused below average, and adjustment to the surrounding environment (Apriyanto, 2012). Based on data from the Bulukumba Regency (2018) there are two extraordinary schools including SLB Darmawanita in Herlang District with 30 mentally retarded children out of 50 students (SLB Darmawanita, 2018). While SLB Negeri 1 Bulukumba with 42 mentally retarded children out of 97 students (SLB Negeri 1 Bulukumba, 2018). So the total number of mentally retarded children is based on two Extraordinary Schools in Bulukumba Regency with a total of 72 people.

A preliminary survey conducted by researchers obtained preliminary data on the number of students taken at SLB Negeri 1 Bulukumba school in the academic year $2017 / 2018$ with the number of students experiencing mental retardation as many as 42 students. where 36 elementary students were students, 24 male students and 12 female students and 6 junior high students, 3 male students and 3 female students. There are categories of mild and moderate mental retardation in which mild mental retardation is 22 students and 20 students are moderate mental retardation. Based on the opinion of the SLB Negeri 1 Bulukumba teacher, the SLB students and other school students are very different. SLB students have limited abilities and are very dependent on the surrounding environment, especially children who experience mental retardation. Based on direct observations made at the State Bulldumba 1 SLSL, it was found that SLB students in terms of parental attention and concern were lacking (SLB Negeri 1).

Prasa research (2012), said that parents who have mentally retarded children will surely experience different challenges compared to those who have normal children. The results showed that the source of parental stress is sourced from individuals, and sources from outside the individual. Both subjects have two sources of coping, namely from within the individual and from outside the individual. The two coping sources can be broken down into 5 aspects, namely social support, values and beliefs, self-control control, and self-esteem. Coping effort strategies used include planning problem solving, positive judgment, self-control, seeking social support, and accepting responsibility. 


\section{COMPRABHENSWE HEAH CARE}

Based on the above background, the researchers formulated the problem "What is the psychological picture of mental retardation children in SLB Negeri 1 Bulukumba".

\section{MATERIAL AND METHODS}

Research design is a method used by researchers to conduct a study that gives direction to the course of research. The design of this study is descriptive research. This research uses descriptive research design with a simple approach is research that focuses on describing and understanding phenomena in the social world from the perspective of individuals who have experience in the social world (Dharma, 2015). The research uses a descriptive design, which aims to get a psychological picture of parents of children with mental retardation in SLB Negeri 1 Bulukumba Regency.

The population in this study were all students who experienced mental retardation in SLB Negeri 1 Bulukumba by 42 students, of which mild mental retardation was 22 and students who experienced moderate mental retardation were 20 students. The sampling technique in this study that is using random sampling is random sampling with a total of 30 samples. The instrument in this study was a questionnaire (questionnaire). The questionnaire was several written questions that were read and answered by research respondents (Suyanto, 2011). The questionnaire uses a Likert and Guttman scale approach, with 20 stress variables assessment criteria there are 4 namely: strongly agree with a score of 4 , agree with a score of 3 , disagree with a score of 2 , strongly disagree with a score of 1 . Then the 20 statement coping variables, there are 2 assessment criteria, namely: yes with a score of 2 , not with a score of 1 . Then do the validity test, research data derived from the questionnaire filled out by respondents must be tested for validity and reliability first. The reason is that the data obtained are truly reliable, so the results of the study can be justified (Sujarweni W., 2014).

\section{RESULTS}

Table 1 Distribution of sex and age characteristics of parents of students in SLB Negeri 1 Bulukumba

\begin{tabular}{llc}
\hline \multicolumn{1}{c}{ Characteristics } & $\mathbf{n}$ & Percentage (\%) \\
\hline Gender & 4 & 13,3 \\
Male & 26 & 86,7 \\
Female & & \\
Age & 23 & 76,7 \\
Young Adult & 7 & 23,3 \\
Old Adult & & 6,7
\end{tabular}




\section{COMPREHENSIEEHAH CARE}

Basic Education

Middle Education

High Education

Bachelor
$8 \quad 26,7$

$10 \quad 33,3$

930,0

$2 \quad 3,3$

\section{Profession}

Housewife

Entrepreneur

Teacer

$\begin{array}{lr}26 & 86,7 \\ 3 & 10,0 \\ 1 & 3,3\end{array}$

\begin{tabular}{ccc}
\hline Amount & 30 & 100,0 \\
\hline
\end{tabular}

Based on table 1, the gender frequency distribution of 30 respondents with the number of male sex is 4 respondents (13.3\%), women are 26 respondents $(86.7 \%)$, the frequency distribution of young adult age is 23 respondents (76, 7\%), 7 adult respondents (23.3\%), frequency distribution of non-school education 2 respondents (6.7\%), SD 8 respondents (26.7\%), SMP 10 respondents (33.3\%) \%), High school as many as 9 respondents (30.0\%), S1 as many as 2 respondents (3.3\%), distribution of IRT work frequencies as many as 26 respondents (86.7\%), self-employed as many as 3 respondents (10.0\%), and teachers as much as 1 respondent (3.3\%).

Table 2. Distribution of the frequency of parental stress on mentally retarded children in SLB Negeri 1 Bulukumba

\begin{tabular}{lcc}
\hline \multicolumn{1}{c}{ Anxiety } & $\mathbf{n}$ & Percentage (\%) \\
\hline Mild & 1 & 3,3 \\
Moderate & 23 & 76,7 \\
Severa & 6 & 20,0 \\
\hline Amount & $\mathbf{3 0}$ & $\mathbf{1 0 0 , 0}$ \\
\hline
\end{tabular}

Based on Table 2 the frequency distribution of mild stress levels is 1 respondent (3.3\%), moderate stress level is 23 respondents (76.7\%), while the level of severe stress is 6 respondents $(20.0 \%)$.

Table 3 Distribution of parents' coping frequency with mental retardation children in SLB Negeri 1 Bulukumba

\begin{tabular}{lcccc}
\hline Coping & $\mathbf{n}$ & \multicolumn{2}{c}{ Percentage (\%) } \\
\hline High & & 27 & & 90 \\
Low & & 3 & & 10 \\
\hline Amount & 30 & & $\mathbf{1 0 0 , 0}$ \\
\hline
\end{tabular}

Based on table 3 the high coping frequency distribution is 27 respondents (90\%), while the low coping frequency is 3 respondents (10\%). 


\section{COMPRAHENSWE HEAH GARE}

\section{DISCUSSION}

Based on the results of research conducted at SLB Negeri 1 Bulukumba, it can be seen that from 30 respondents who experienced mild stress as much as 1 respondent (3.3\%), moderate stress as many as 23 respondents or approximately (76.7\%), while severe stress as much as 6 respondents or around (20.0\%). Stress is a dual emotion (multi emotion) that is not a single emotion. According to (Dwight, 2004) stress is a feeling of doubt about its ability to cope with something because the available inventory cannot meet the demands of it. Dwight stresses the notion of stress on feeling doubtful or anxious about his abilities. Stressful situations tend to cause extra effort and new adjustments, but in a long time that will weaken individual defenses and cause dissatisfaction (Saam \& Wahyuni, 2013).

In line with research conducted by (Prasa, 2012) said that parents who have mentally retarded children will surely experience a variety of different challenges compared to those who have normal children. Various sources of stress they experience are certainly different from parents in general. sources of parental stress are those that come from individuals, and sources from outside the individual. Meanwhile, according to the results of research conducted by (Triana \& Andriany, 2010) shows that stressors of families with older children are sacrifices of work time, finance, enforcement of discipline, community stigma, stunted child growth and future concerns of children.

Researchers believe that parental stress in SLB Negeri 1 Bulukumbada is at mild stress levels. This is due to the family support that unceasingly provides support or encouragement that having a child who is mentally retarded is a gift from God so that the child must be treated or educated properly as with a normal child.

Based on the results of research conducted at SLB Negeri 1 Bulukumba, it can be seen that from 30 respondents who have high coping as many as 27 respondents (90\%), while low coping as much as 3 respondents (10\%). Coping is someone who experiences stress or psychological tension in dealing with problems of daily life that require support from the environment so that it can reduce stress (Rasmun, 2009). According to the results of research (Triana \& Andriany, 2010) that parental coping brings its impact, both for the environment and for mentally retarded children themselves. The results of the study stated that the coping of parents with mentally retarded children did not affect the environment. This statement was obtained from interviews with participants who stated that the coping used by parents did not affect the environment. parents of 


\section{COMPRABHENSWE HEAH CARE}

children with mental retardation include three things, namely bringing a little change in mental retardation, does not bring significant changes and mental retardation children become more disciplined.

Researchers believe that parental coping or ways to deal with parental coping problems are very high because parents in SLB Negeri 1 Bulukumba always be kind and patient with their children's behavior and always try to seek treatment for their children to recover and always teach their children to be disciplined and always adjust yourself towards the state of the child. This study is in line with research (Triana \& Andriany, 2010) that families try to find alternative treatments in various places such as therapists and acupuncture massage so that children can recover and always be resigned and patient towards children.

\section{CONCLUSIONS}

Distribution of the number of respondents based on the level of stress of parents to mental retardation children in SLB Negeri 1 Bulukumba in 2018 ie parents who have moderate stress levels more than parents who have mild and severe stress levels. Distribution of the number of respondents based on parent coping with mental retardation children in SLB Negeri 1 Bulukumba in 2018, namely parents who have high coping as many as 27 respondents while parents who have low coping are 3 respondents. 2. It is recommended that parents who have mentally retarded children be more accepting and more patient with the child's condition and get closer to God Almighty.

\section{REFERENCES}

Ambarwati, F. R., \& Nasution, N. (2012). Buku pintar asuhan keperawatan jiwa. Yogyakarta: cakrawala ilmu.

Apriyanto, N. (2012). Seluk Beluk Tunagrahita \& Strategi pembelajarannya. Jogjakarta: Javalitera.

Dharma, K. K. (2015). Metodologi Penelitian Keperawatan. Jakarta: CV. Trans Info Media. Gusmawan, S. (2017). Kondisi psikologis orangtua yang memiliki anak gangguan jiwa di desa kilangan kecamatan singkil kabupaten aceh singkil.

Indriana, Y., Kristiana, I. F., A.Sonda, A., \& Intanirian, A. (2010). tingkat stres

lansia di panti wredha pucang gading semarang. jurnal psikologi undip.

Keliat, B. A., Akomat, Helena, N., \& Nurhenia, H. (2007). keperawatan kesehatan jiwa komunitas. jakarta: EGC.

Kusumawati, F., \& Hartono, Y. (2010). Keperawatan jiwa. Jakarta: Salemba Medika. Litiloly, F., \& swastiningsih, N. (2014). manajemen stres pada istri yang mengalami long distance marriage. jurnal fakultas psikologi. 
Lubis, R., Irma, N. H., wulandari, R., Siregar,K., Tanjung, N. A., Wati, T. A., et al. (2015). coping stress pada mahasiswa yang bekerja. bekerja coping,stres.

Mansur, H. (2009). Psikologi ibu dan anak. jakarta selatan: Salemba Medika.

Maryam, S. (2017). strategi coping.teori dan sumberdayanya. jurnal konseling.

Notoatmodjo, S. (2012). Metodologi penelitian kesehatan. Jakarta: Rineka cipta.

Pieter, H. Z., Janiwarti, B., \& saragih, m. (2011). Pengantar psikologi untuk keperawatan. Jakarta: Kencana.

Prasa, B. A. (2012). Stres dan koping orangtua dengan anak retardasi mental. fakultas psikologi.

Prawira, P. A. (2016). Psikologi umum. Jogjakarta: Ar-ruzz media.

Rasmun. (2009). teori dan pohon masalah keperawatan. jakarta.

Rosiana, A., \& Arini, R. (2017). pengaruh psikoedukasi keluarga terhadap kemampuan perawatan diri toeliting pada anak retardasi mental di SDLB purwosari.

Rosiana, A., \& Tiara, N. (2017). Indonesia jurnal perawat. pengaruh psikoedukasi keluarga terhadap kemampuanperawatan kebersihan diri pada anak retardasi mental di SDLB purwosari kudus tahun2015.

Saam, Z., \& Wahyuni, S. (2013). Psikologi Keperawatan. Jakarta: Rajawali Pers.

Sujarweni, V. W. (2014). Metodologi penelitian keperawatan. Yogyakarta.

Syamsuddin, Muriyati, Asnidar, \& Sumarni. (2015). Pedoman praktis metodologi penelitian internal. Ponorogo: CV. Wade group.

Triana, N. Y., \& Andriany, M. (2010). stres dan koping keluarga dengan anak tunagrahita. program studi ilmu keperawatan.

Wahono, D. L., \& Sudarji, S. (2016). coping stres pada orang tua anak dengan leukimia limfositik akut. jurnal psikologi psibernetika. 